\title{
NUMERICAL ANALYSIS OF STRAIN AND STRESS STATE IN CYLINDRICAL NOTCHED TENSILE SPECIMENS
}

\section{DERPENSKI, A. SEWERYN}

\author{
Bialystok University of Technology, Poland
}

\begin{abstract}
The paper presents the numerical results of stress and strain distribution in specimens with various sizes of notches in monotonic uniaxial tensile tests. The adopted method involves the finite element method and the elastic-plastic model of material with hardening. The distribution of the principal strain, principal stress and maximum plastic shear strain in the plane of notch symmetry is shown in figures.
\end{abstract}

Keywords: numerical analysis, fracture of specimen with notches, ductile fracture.

The process of material fracture is the result of physical processes on a microscopic scale [1-3]. At the macroscopic scale the values of state variables, which are components of stress and strain tensors and their variation during loading are responsible for fracture [4]. These values are determined with the help of numerical calculations, e.g. using the finite element method (FEM). The presence of stress and strain concentrations, for example notches, has an influence on the elements fracture $[5,6]$. The experimental research does not provide the possibility of determining the values of local state variables, such as components of stress and strain tensors, or the components of displacement vectors at each specimen point, and especially inside the material. With this goal in mind the use of a numerical method is essential. This paper presents the results of numerical modeling of stress and strain fields in tensile (to the point of critical load) specimens with different shapes of notches, made of aluminum alloys EN-AW 2024 (the results of the experimental research are shown in paper [7]). Taking into account nonlinear analysis and the material nonlinearity (elasto-plastic material model with work-hardening) of the modeled problem, the finite element method was used.

Numerical analysis. The distribution of stresses and strains in the specimens with notches, and the unnotched specimens made of aluminum alloy EN-AW 2024, was studied by the MSC.MARC software, based on the finite element method. In the calculations the axial symmetry of the specimen and the notch symmetry (Fig. 1) were taken into consideration. The four-node axis-symmetric finite elements were applied. Nonlinear analysis with material non-linearity was taken into consideration. The dimensions of the specimens used in the analysis are shown in the Table. Also the maximal stress value $\sigma_{\max }$ and critical load $F_{c}$ for different shape of a notch are shown in this table. In the analysis eight radii $r_{K}$ of the U-type notch were used: $0.3,0.5,1,2,4,8,15,30 \mathrm{~mm}$.

The boundary conditions (Fig. 1c) were applied in the calculation: the axial symmetry of the geometric model ( $u_{r}=0$ on the specimen axis), notch symmetry $\left(u_{z}=0\right.$ on the plane of the notch symmetry). The loading of the numerical calculation was done with the help of the set displacement $u_{c}$ of the measurement base (see Table), which were calculated for each specimen type directly as a result of the experiment [7]. In order to describe the relationship between the stress and strain in the specimens, an elastic and plastic material model with isotropic hardening was used. The Huber-von Misses plasticity yield criteria was applied. The curve of material hardening was obtained

Corresponding author: L. DERPENSKI, e-mail: I.derpenski@pb.edu.pl 
from paper [7]. Fig. 2 shows the actual hardening $\sigma-\varepsilon$ curves received in the complete range for aluminum alloys.
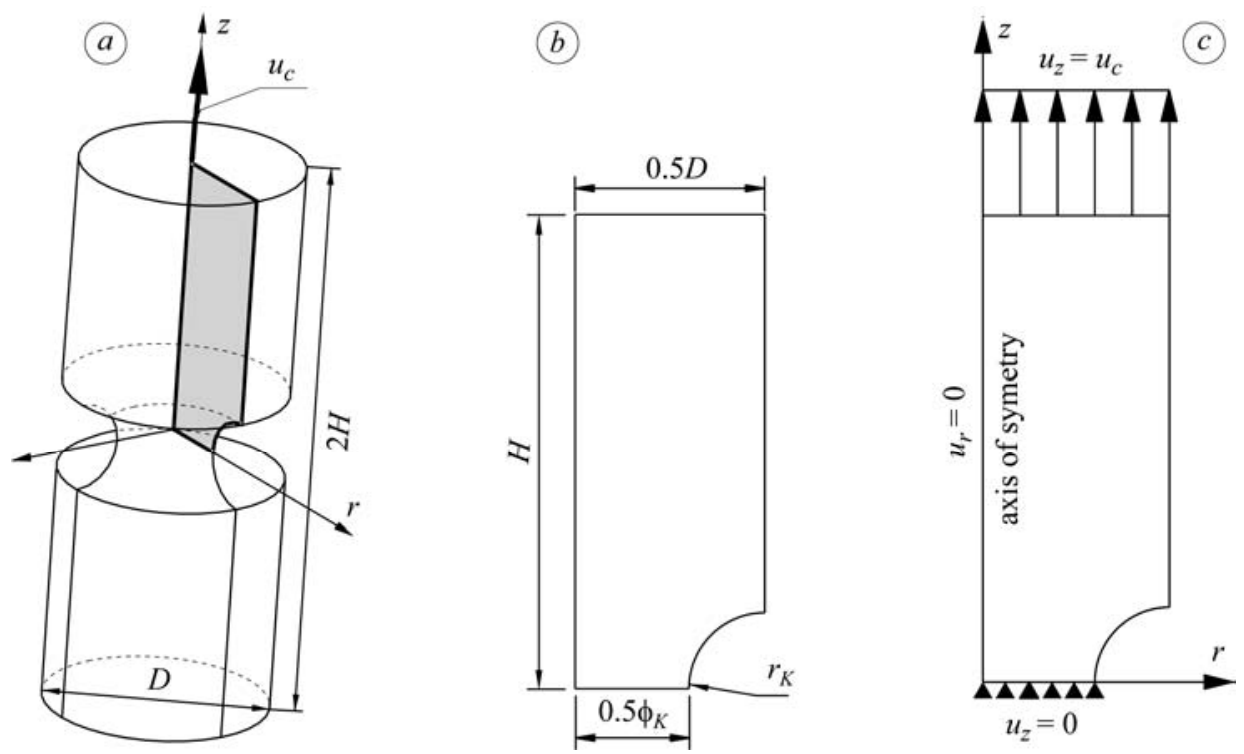

Fig. 1. The 3D specimen (a), the shape of model used in numerical calculation $(b)$, boundary conditions and loads $(c)$.

The dimensions of specimens and value of critical load $(2 \mathrm{H}=25 \mathrm{~mm}, D=10 \mathrm{~mm})$

\begin{tabular}{|c|c|c|c|c|c|c|c|c|c|c|c|c|c|}
\hline \multicolumn{2}{|c|}{ № of specimen } & 1 & 2 & 3 & 4 & 5 & 6 & 7 & 8 & 9 & 10 & 11 & 12 \\
\hline \multirow{2}{*}{$\begin{array}{l}\frac{1}{0} \\
\stackrel{0}{\Xi} \\
\stackrel{0}{0}\end{array}$} & $r_{K}, \mathrm{~mm}$ & \multicolumn{3}{|c|}{0.3} & \multicolumn{3}{|c|}{0.5} & \multicolumn{3}{|c|}{1.0} & \multicolumn{3}{|c|}{2.0} \\
\hline & $\phi_{K}, \mathrm{~mm}$ & 6 & 7 & 8 & 6 & 7 & 8 & 6 & 7 & 8 & 6 & 7 & 8 \\
\hline \multirow{3}{*}{ 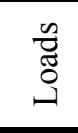 } & $u_{c}, \mathrm{~mm}$ & 0.25 & 0.38 & 0.58 & 0.35 & 0.46 & 0.73 & 0.48 & 0.64 & 1.07 & 0.67 & 1.02 & 1.63 \\
\hline & $F_{c}, \mathrm{kN}$ & 19.1 & 23.5 & 26.7 & 19.8 & 23.7 & 27.5 & 19.7 & 24.1 & 28.6 & 18.2 & 24.1 & 29.5 \\
\hline & $\sigma_{\max }, \mathrm{MPa}$ & 244 & 300 & 339 & 253 & 302 & 350 & 251 & 307 & 365 & 232 & 307 & 375 \\
\hline \multicolumn{2}{|c|}{ № of specimen } & 13 & 14 & 15 & 16 & 17 & 18 & 19 & 20 & 21 & 22 & 23 & 24 \\
\hline \multirow{2}{*}{ 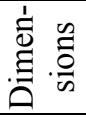 } & $r_{K}, \mathrm{~mm}$ & \multicolumn{3}{|c|}{4.0} & \multicolumn{3}{|c|}{8.0} & \multicolumn{3}{|c|}{15.0} & \multicolumn{3}{|c|}{30.0} \\
\hline & $\phi_{K}, \mathrm{~mm}$ & 6 & 7 & 8 & 6 & 7 & 8 & 6 & 7 & 8 & 6 & 7 & 8 \\
\hline \multirow{3}{*}{ 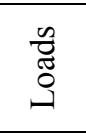 } & $u_{c}, \mathrm{~mm}$ & 0.73 & 1.10 & 2.00 & 1.11 & 1.23 & 2.06 & 1.57 & 1.71 & 2.14 & 2.10 & 2.29 & 2.62 \\
\hline & $F_{c}, \mathrm{kN}$ & 16.3 & 22.3 & 28.5 & 15.2 & 20.1 & 27.3 & 14.5 & 19.6 & 26.0 & 13.7 & 19.3 & 25.1 \\
\hline & $\sigma_{\max }, \mathrm{MPa}$ & 207 & 283 & 363 & 193 & 256 & 348 & 184 & 250 & 330 & 174 & 245 & 320 \\
\hline
\end{tabular}

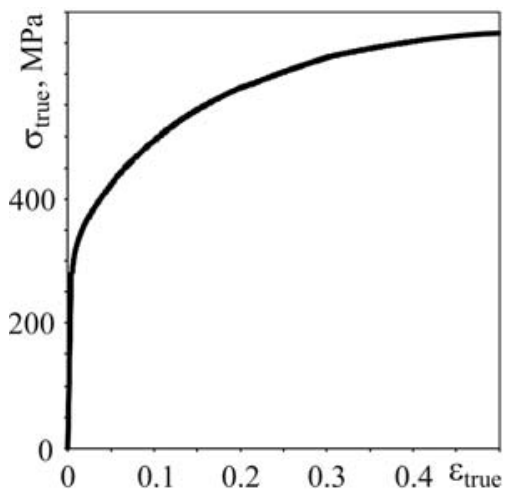

Fig. 2. Stress-strain curve for aluminum alloy EN-AW 2024: $E=69.65 \mathrm{GPa}, v=0.34$, $R_{e}=260 \mathrm{MPa}, R_{u}=658 \mathrm{MPa}$.

The analysis determined the influence of the notch shape on stress and strain fields in the whole loading range, the development of plastic zone and the position of the maximum stress and plastic strain value in the specimen. Some of them have already been presented in [7]. In the tested specimen, under the tensile load influence in the plastic zone, the notch generated 
a tri-axial stress state. At the moment of fracture determined by the $u_{c}$ and the $F_{c}$ taken from experimental research, the largest value was noted in $\sigma_{z z}$. Therefore, it was assumed that this component has the greatest influence on fracture initiation. Attention was focused on the location of the maximum value of $\sigma_{z z}$ in the specimen, depending on the value of $r_{K}$.

Based on the results it was found that the distribution of $\sigma_{z z}$ depends on the $r_{K}$ size. For notches with larger radii $\left(r_{K} \geq 2 \mathrm{~mm}\right)$ these values are located on the specimen axis. In the case of notches with smaller radii $\left(r_{K}<2 \mathrm{~mm}\right)$ the maximum value of $\sigma_{z z}$ is found at the notch root (Fig. 3). The zone of $\sigma_{z z}$ maximum values is very concentrated and it changes with the increase of the notch radius. Increasing the radius of the notch from $r_{K}=0.3 \mathrm{~mm}$ to $r_{K}=1 \mathrm{~mm}$, the zone increases without changing its location and remains in the vicinity of the notch root. When $r_{K}$ exceeds $1 \mathrm{~mm}$, this zone shifts towards the specimen axis. Further increases of $r_{K}$ do not change the zone shape.
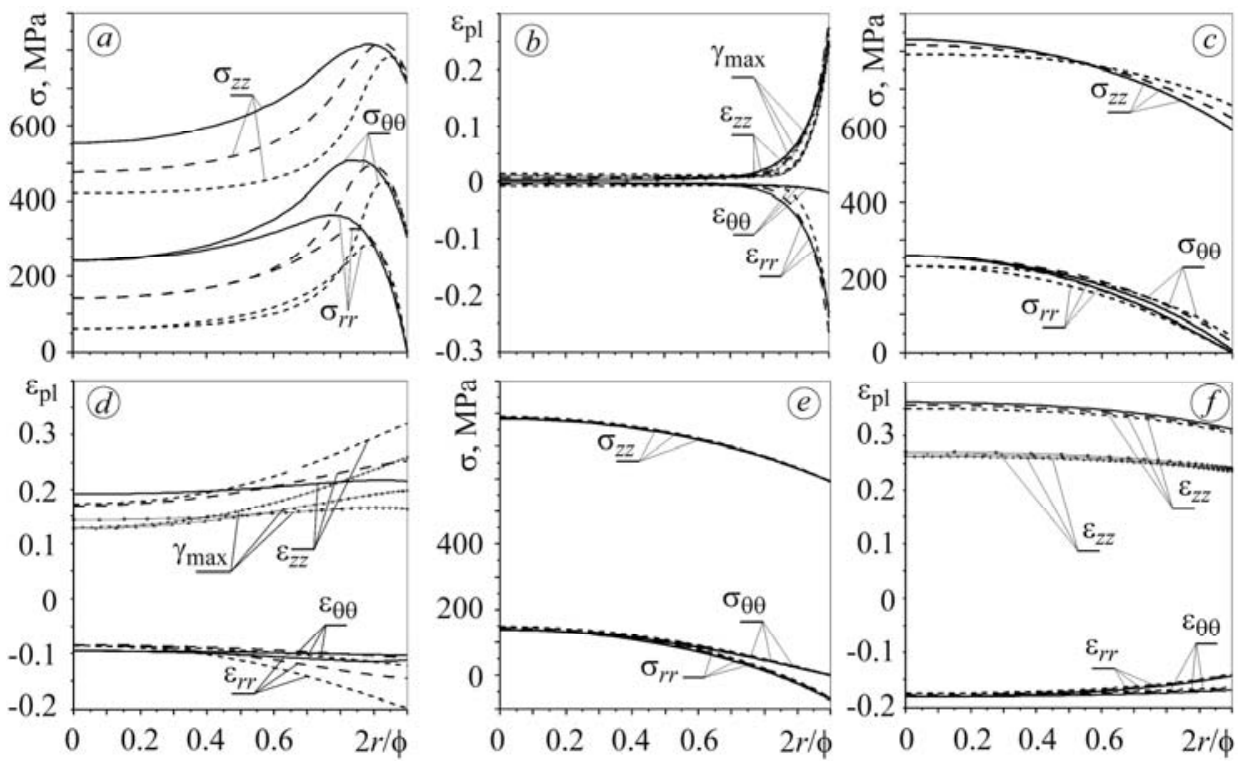

Fig. 3. The distribution of stress $(a, c, e)$ and plastic strain $(b, d, f)$ in the symmetry plane of the notch at the moment of maximal load: $r_{K}=0.3 \mathrm{~mm}(a, b) ; 4 \mathrm{~mm}(c, d) ; 30 \mathrm{~mm}(e, f)$. $\smile-\phi_{K}=6 \mathrm{~mm} ; \hookrightarrow-7 \mathrm{~mm} \longrightarrow \smile-8 \mathrm{~mm}$.

It should be noted that in the case of specimens with $r_{K}=0.3$ and $r_{K}=0.5 \mathrm{~mm}$ plasticization did not take place in the entire cross-section of the notch plane symmetry. In specimens with $r_{K}=1$ and $r_{K}=2 \mathrm{~mm}$ under the critical load $F_{c}$ the cross-section in the specimen plane symmetry a complete plasticization occured. Still the difference in values of stresses at the notch root and at the axis were very wide. Almost equal plasticization took place in the whole cross-section in the remaining specimens with notches $\left(r_{K}=4,8,15,30 \mathrm{~mm}\right)$. The above refers to the specimens made of both aluminum alloys. From the experimental research it is known that the fracture surface depends on the notch radius and partially or fully covers the notch plane of symmetry. Therefore, the distributions of stress and strain fields were subjected to detailed analysis in the notch plane of symmetry where the fracture initiated. Figure 3 presents the selected distributions: stress and plastic strain tensor components, the maximal plastic shear strain under critical load. The values of $r$ (distance from the specimen axis) were normalized by $\phi_{K}$.

The numerical calculations showed the place where the maximal normal stress and the maximal plastic strain depends on the shape of the notch, and that $r_{K}$ has a greater 
influence on the stress distribution than $\phi_{K}$. Comparing the location of the maximum value of $\sigma_{z z}$ and $\varepsilon_{z z}^{p}$ and $\gamma_{\max }^{p}$ it is important to note that for the notches with a larger radius $\left(r_{K} \geq 2 \mathrm{~mm}\right)$ these values are found on the specimen axis, therefore at this point fracture initiation should be expected. In the case of notches with smaller radii $\left(r_{K}<2 \mathrm{~mm}\right)$, the maximum stress values are found near the notch root, while the maximum strain values are placed exactly at the notch root. Therefore, the location of crack initiation in this case is not clearly defined. The calculation shows that the fracture of specimens with $r_{K}$ bigger than $2 \mathrm{~mm}$ occurs in a similar way as for smooth specimens. For these radii fracture initiation occurs in the same place on the axis of specimen symmetry [7].

\section{CONCLUSION}

On the basis of the numerical calculation of stress and strain fields and the earlier experimental researches conducted on the specimens with notches made of the aluminum alloy EN-AW 2024 one can state that normal stress vector component on the critical plane determines the fracture. This plane, in the case of tensile specimens with notches, is perpendicular to the load direction. The value of the critical normal stress may be dependent on the maximal plastic shear strains, assuming that the accumulated damages (and material weakening) occurs faster on the free surface than inside the material.

РЕЗЮМЕ. Методом скінченних елементів отримано числовий розв'язок пружно-пластичної осесиметричної задачі про розтяг циліндричного зразка з поверхневою U-подібною канавкою. Числові результати одержано для зразка 3 алюмінієвого сплаву EN-AW 2024. Проаналізовано розподіл напружень і деформацій у симетричному поперечному перерізі зразка залежно від відносного радіуса закруглення у вершині канавки, коли розтягальна сила досягає критичного значення перед руйнуванням зразка.

РЕЗЮМЕ. Методом конечных элементов получено числовое решение упругопластичной осесимметричной задачи о растяжении цилиндрического образца с поверхностной $\mathrm{U}$-подобной канавкой. Числовые результаты получены для образца из алюминиевого сплава EN-AW 2024. Проанализировано распределение напряжений и деформаций в симметричном поперечном сечении образца в зависимости от относительного радиуса закругления в вершине канавки, когда растягивающая сила достигает критического значения перед разрушением образца.

This study was carried out in compliance with the plan of the N-N501-120536 research project of Ministry of Science and Higher Education, Poland.

1. Thomason P. F. Ductile fracture of metals. - NY: Pergamon Press, 1990. -223 p.

2. Experimental and numerical investigations of ductile damage in aluminum alloy / A. Öchsner, J. Gegner, W. Winter, and G. Kuhh // Mater. Sci. Eng. - 2001. - A318. - P. 328-333.

3. Bandsta J. P. and Koss D. A. A simulation of growth and coalescence of void during ductile fracture // Mater. Sci. Eng. - 2004. - 387. - P. 399-403.

4. Bao Y. Comparative study on various Fracture criteria. Part II: Finite Element Analysis. - Cambridge: MIT, 2001. $-40 \mathrm{p}$.

5. Bao $Y$. Dependence of ductile crack formation in tensil tests on stress triaxiality, stress and strain ratios // Eng. Fract. Mech. - 2005. - 72. - P. 505-522.

6. Calibration and evaluation of fracture models / T. Wierzbici, Y. Bao, Y. W. Lee, and Y. Bai // Int. J. Mech. Sci. - 2005. - 47. - P. 719-743.

7. Derpeński L. and Seweryn A. Experimental research into fracture of EN-AW 2024 and EN-AW 2007 aluminum alloy specimens witch notches subjected to tension // Exp. Mech. - 2011. - 51. - P. 1075-1094.

8. Venugopal R., Ramakrishnan N., and Krishna Kumar R. A comparative evaluation of the theoretical failure criteria for workability in cold forging // J. Mater. Process. Technol. - 2003. - 142. - P. 29-42.

9. Ozturk F. and Lee D. Analysis of forming limits using ductile fracture criteria // J. Mater. Process. Technol. - 2004. - 147. - P. 397-404.

10. Han H. N. and $\operatorname{Kim} K$. H. A ductile fracture criterion in sheet metal forming process // J. Mater. Process. Technol. - 2003. - 142. - P. 231-238. 